\section{Bush asks for 13 per cent extra for science}

- Education called top priority

\section{- Initiatives in 'global change', computing}

\section{Washington}

IT is budget time in Washington again, the time of year when the president lets his policy priorities be known through the budget he submits to the US Congress.

President George Bush this week asked Congress to approve a research and development budget totalling $\$ 75,600$ million, an increase of $\$ 8,400$ million or 13 per cent over research and development (R\&D) spending for the current fiscal year, 1991. Basic research would claim $\$ 13,300$ million of the R\&D total, an increase of 8 per cent, while new funds for applied research and development would jump to almost $\$ 60,000$ million, a 13 per cent rise.

White House science adviser D. Allan Bromley declares that "it's a good budget", with special emphasis on science, as well as science education. In the light of the fact that the President's budget overall requests funding increases in the range of 2.6 per cent, it is evident that science has fared well.

However, because the 13 per cent figure for R\&D increases does not take inflation into account - currently between 5 per cent and 6 per cent - the real increases are not as sub-stantial as the Administration suggests.

The real outcome of the lengthy US budget process will not be known until sometime next autumn when Congress makes its own decisions about the budget. If history is any guide, legislators will ultimately spend more on biomedical research than the president requests, while cutting back somewhat on defence spending. However, in the light of the technilion. as priority areas. cal success of arms such as the Patriot missile in the Gulf war, high-technology military research may find a receptive audience on Capitol Hill this year.

One of the most contentious issues in US science these days is the disparity between the numbers of individual scientists who are applying for grants and the government's capacity to fund them. Bromley notes that within the National Institutes of Health, the Bush budget asks for a 9 per cent increase in funds for investigator-initiated grants. At the National Science Foundation, which also funds a large number of individual investigators, the proposed increase is for 16 percent to a total of $\$ 2,100$ million.

Overall in the Bush budget, however, projects that fall into the category of "big science" have fared best. The Superconducting Super Collider is on course at $\$ 534$ million for fiscal year 1992. The National Aeronautics and Space Administration may get a big increase for projects including exploration of the Solar System and new launch systems for the space shuttle. And the Human Genome Project, which Bromley describes as a "vital national asset" is in line for a $\$ 334$ million increase for basic research.

This would bring the US investment in deciphering the genome to $\$ 5,000 \mathrm{mil}$ -

High performance computing and communications, national security R\&D and biotechnology were also singled out

Budget proposals for the principal science agencies and science programmes see next page

\begin{tabular}{|c|c|c|c|c|}
\hline \multicolumn{5}{|c|}{ RESEARCH AND DEVELOPMENT SPENDING ( $\$$ MILLION) } \\
\hline Basic research & $\begin{array}{c}1991 \\
\text { Enacted }\end{array}$ & $\begin{array}{c}1992 \\
\text { Proposed }\end{array}$ & $\begin{array}{l}\text { Dollar } \\
\text { change }\end{array}$ & $\begin{array}{l}\text { Per cent } \\
\text { change }\end{array}$ \\
\hline Doubling the NSF budget & 2,316 & 2,722 & +406 & +18 \\
\hline Basic biomedical research at NIH & 4.634 & 4.968 & +334 & +7 \\
\hline Human Genome Project & 135 & 169 & +35 & +26 \\
\hline Agricultural Research Initiative & 73 & 125 & +52 & +71 \\
\hline Superconducting Super Collider & 243 & 534 & +291 & +120 \\
\hline \multicolumn{5}{|l|}{ Applied research } \\
\hline Computing and communications & 489 & 638 & +149 & +30 \\
\hline Energy R\&D & 676 & 903 & +227 & +34 \\
\hline Advanced manufacturing and materials & 1,316 & 1,310 & -6 & - \\
\hline HIV/AIDS & 1,152 & 1.210 & +58 & +5 \\
\hline Moving Fusion Energy from Science to Engineering & 275 & 337 & +62 & +23 \\
\hline Aeronautics R\&D & 482 & 543 & +61 & +13 \\
\hline Expanding R\&D at the NIST & 215 & 248 & +33 & +15 \\
\hline Defence R\&D & 37,738 & 43,247 & +5.464 & +14 \\
\hline \multicolumn{5}{|l|}{ Space exploration: } \\
\hline Space transportation infrastructure & 4.801 & 5.517 & +716 & +15 \\
\hline Space science & 1.774 & 2.141 & +367 & +21 \\
\hline Mission to Planet Earth & 954 & 1.186 & +232 & +24 \\
\hline Mission From Planet Earth & 2.199 & 2,470 & +271 & +12 \\
\hline Biotechnology & 3,788 & 4,107 & +319 & +8 \\
\hline
\end{tabular}

\section{All change at the top}

\section{London}

ThE Universities Funding Council (UFC) has poached the chairman-elect of the Committee of Vice-Chancellors and Principals (CVCP) to be its next chief executive. Graeme Davies, vice-chancellor of the University of Liverpool, was to have taken over at the CVCP at the end of June, but will now replace Sir Peter SwinnertonDyer at the UFC on 1 April.

The universities must wait to see how the balance of power between the new UFC chief executive and his chairman, Lord Chilver, evolves. There have been many reports of friction between Chilver and Swinnerton-Dyer, who chaired the old University Grants Committee before its replacement with the UFC in 1989. Some vice-chancellors fear that Chilver, an advocate of university expansion without a proportionate increase in government funding, will now assume a stronger role. P.A.

\section{Raising the profile}

THE funding crisis currently facing British science is to be debated in the House of Commons this week. Jeremy Bray, science and technology spokesman for the opposition Labour party, which requested the debate, says that Labour will attack the "creative accounting" that has allowed the government to claim that the 1991-92 budget for the research councils will keep pace with inflation.

In recent weeks, British science policy has shown some signs of moving from its customary place on the political backburner. The launch of a major policy inquiry by the Royal Society (see Nature 349,$183 ; 17$ January 1991) was followed last week by a meeting between Prime Minister John Major and a small group of leading British scientists, organized by Conservative Member of Parliament Sir Ian Lloyd.

Both Downing Street officials and the scientific delegation said they were satisfied with the one and a half hour meeting, although any major policy changes still seem to be off the short-term agenda. P.A.

\section{Polys gain}

THE Polytechnics and Colleges Funding Council (PCFC) will spend an extra $£ 7 \cdot 3$ million on research in 1991-92, in addition to its existing spending of about $£ 30$ million. The money will be distributed by a new committee, yet to be appointed, to selected polytechnics and colleges with a good research record.

The move follows a PCFC-sponsored report which last year recommended that the PCFC should increase its research spending by $£ 28$ million a year.

Peter Aldhous 